\title{
Analisis Kemampuan Representasi Matematis Siswa dengan Model Group Investigation Pada Materi Turunan
}

\author{
1Putri Sucita Sari, ${ }^{2}$ Nindy Citroresmi Prihatiningtyas, ${ }^{3}$ Citra Utami \\ Pendidikan Matematika, STKIP Singkawang \\ Jl. STKIP, Kel. Naram, Kec. Singkawang Utara, Singkawang, 79251 \\ Email: sucitasarip@gmail.com
}

\section{Article History:}

Received: 17-02-2020; Received in Revised: 21-09-2020; Accepted: 27-09-2020

\begin{abstract}
The mathematical representation ability of students at a Senior High School in Singkawang is still low. This is due to the habit of students receiving direct learning and passive activities. This article tries to find out the differences in mathematical representation abilities between students who are given the Group Investigation (GI) learning model and students who are given the direct learning model and describe the mathematical representation abilities of students in terms of learning activities with the GI learning model. The results showed that there were differences in the increase in the mathematical representation ability of students who were given the GI learning model and those who were given the direct learning model. The active mathematical representation ability of students is in the high category, while students with moderate and passive activities have moderate representation skills.
\end{abstract}

Keywords: Group Investigation (GI); Mathematical Representation Ability; Student Learning Activities

\begin{abstract}
Abstrak
Kemampuan representasi matematis siswa di salah satu SMA Negeri di Singkawang masih rendah. Hal ini dikarenakan kebiasaan siswa menerima pembelajaran langsung dan aktivitas yang pasif. Artikel ini mencoba mengetahui perbedaan kemampuan representasi matematis antara siswa yang diberikan model pembelajaran Group Investigation (GI) dengan siswa yang diberikan model pembelajaran langsung serta mendeskripsikan kemampuan representasi matematis siswa ditinjau dari aktivitas belajar dengan model pembelajaran GI. Hasil penelitian menunjukkan terdapat perbedaan peningkatan kemampuan representasi matematis siswa yang diberikan model pembelajaran GI dengan siswa yang diberikan model pembelajaran langsung. Kemampuan representasi matematis siswa yang aktif berada pada kategori tinggi, sedangkan siswa degan aktivitas sedang dan pasif memiliki kemampuan representasi sedang.
\end{abstract}

Kata kunci: Group Investigation (GI); Kemampuan Representasi Matematis; Aktivitas Belajar Siswa. 


\section{Pendahuluan}

Tujuan pembelajaran matematika berdasarkan Permendikbud no 58 tahun 2014 adalah sebagai berikut : 1) Memahami konsep matematika, 2) Menggunakan pola sebagai dugaan dalam penyelesaian masalahan, 3) Menggunakan penalaran pada sifat, 4) Mengkomunikasikan gagasan, 5) Memiliki sikap menghargai kegunaan matematika dalam kehidupan, 6) Memiliki sikap dan perilaku yang sesuai dengan nilai-nilai dalam matematika dan pembelajarannya, 7) Melakukan kegiatan motorik yang menggunakan pengetahuan matematika, 8) Menggunakan alat peraga sederhana. Kemampuan komunikasi merupakan salah satu tujuan dari pembelajaran matematika yang terdapat pada nomor (4) yaitu mengkomunikasikan gagasan, kemampuan komunikasi kuat hubungannya dengan kemampuan representasi. Hal ini dikarenakan untuk dapat mengkomunikasikan sesuatu, seseorang perlu representasi baik berupa gambar, grafik, diagram, maupun bentuk representasi lainnya ${ }^{1}$. Alasan mengapa kemampuan representasi harus dimiliki oleh siswa karena dengan kemampuan representasi yang baik dapat membantu siswa dalam mengorganisasikan pemikiran mereka ketika menyelesaikan masalah atau soal ${ }^{2}$. Namun pada kenyataannya siswa tidak memiliki kemampuan representasi yang baik.

Pernyataan ini diperkuat dengan penelitian Izwita Dewi, Sahat Saragih, dan Dewi Khairani yang dilakukan pada siswa kelas X SMA Istiqlal Delitua yang menunjukan kemampuan representasi siswa laki-laki lebih rendah dari pada siswa perempuan ${ }^{3}$. Rendahnya kemampuan representasi matematis siswa juga ditemukan disalah satu SMA Negeri di Singkawang. Hal ini diperkuat dari hasil prariset yang dilakukan oleh peneliti di sekolah tersebut dengan memberikan soal yang memuat indikator kemampuan representasi siswa. Hasil prariset menunjukkan bahwa kemampuan representasi matematika siswa masih tergolong rendah. Salah satu penyebab rendahnya kemampuan representasi siswa juga dipengaruhi oleh aktivitas belajar siswa yang masih tergolong rendah. Hal ini dapat terlihat dari kurangnya partisipasi siswa dan keterlibatan siswa di dalam kelas baik secara fisik maupun mental, sehingga siswa tergolong tidak aktif.

\footnotetext{
1 Muhamad Sabirin, "Representasi dalam Pembelajaran Matematika," Jurnal Pendidikan Matematika 1, no. 2 (August 19, 2014): 33-44, https://doi.org/10.18592/jpm.v1i2.49.

2 Hani Handayani, "Pengaruh Pembelajaran Kontekstual Terhadap Kemampuan Pemahaman Dan Representasi Matematis Siswa Sekolah Dasar," Didaktik: Jurnal IImiah PGSD STKIP Subang 1, no. 1 (December 31, 2015): 142-49, https://doi.org/10.36989/didaktik.v1i1.20.

${ }^{3}$ Izwita Dewi, Sahat Saragih, and Dewi Khairani, "Analisis Peningkatan Kemampuan Representasi Matematis Siswa SMA Ditinjau Dari Perbedaan Gender," Jurnal Didaktik Matematika 4, no. 2 (October 4, 2017): 115-24, https://doi.org/10.24815/jdm.v4i2.8863.
} 
Penerapan model pembelajaran langsung dan kurangnya penerapan sistem kerja kelompok dalam pembelajaran kooperatif juga menjadi salah satu alasan rendahnya kemampuan representasi matematis siswa. Sebenarnya hal ini tidak perlu terjadi jika guru benar-benar melaksanakan pembelajaran kooperatif yang sesuai dengan prosedur yang telah ditentukan. Pembelajaran kooperatif penting diterapkan hal ini disampaikan oleh Syunita karena salah satu model pembelajaran yang dapat digunakan agar siswa terlibat secara aktif dalam belajar adalah model pembelajaran kooperatif ${ }^{4}$. Selaras dengan pernyataan tersebut, hasil penelitian Nurhayati juga menunjukan bahwa pembelajaran cooperative learning mampu memotivasi siswa untuk menjadi aktif dalam pembelajaran, dengan belajar kelompok akan terjadi saling tukar pikiran, tidak ada lagi kesenjangan antara siswa karena semuanya saling berinteraksi satu sama lainnya ${ }^{5}$. Salah satu model pembelajaran kooperatif adalah Group Investigation (GI). Sudarsana menyatakan filosofi model pembelajaran kooperatif GI adalah konstruktivisme, yang dalam proses pembelajaran tidak mentransfer pengetahuan dari guru ke siswa, tetapi siswa sendiri yang aktif mencari sesuatu dan membangun pengetahuannya sendiri ${ }^{6}$.

Karunia menetapkan tujuh tahapan yang dilakukan siswa dalam GI seperti berikut ini: siswa membentuk kelompok, siswa memilih topik dan merencanakan prosedur belajar, mengumpulkan, menganalisis, dan mengevaluasi informasi, mempersiapkan laporkan dan setiap kelompok mempresentasikan hasil penyelidikannya, setelah itu guru dan siswa mengevaluasi tentang pembelajaran yang telah dilaksanakan. ${ }^{7}$ Adapun kelebihan dari model pembelajaran GI yang dikemukakan oleh N. Irawan, F. J., \& Ningrum yaitu: 1) mampu meningkatkan keaktifan dan kreatifitas dalam belajar; 2) kerjasama tim; 3) mempertanggung jawabkan jawaban yang diberikan $^{8}$. Berdasarkan hal tersebut, pada penelitian ini akan diterapkan

4 Seswira Yunita, Lies Andriani, and Ade Irma, "Pengaruh Penerapan Model Pembelajaran Kooperatif Tipe Group Investigation Terhadap Kemampuan Pemecahan Masalah Matematis Ditinjau Dari Motivasi Belajar Siswa Sekolah Menengah Pertama Di Kampar," JURING (Journal for Research in Mathematics Learning) 1, no. 1 (May 27, 2018): 11-18, https://doi.org/10.24014/juring.v1i1.4700.

5 Sugi Nurhayati, "Meningkatkan Aktivitas Dan Hasil Belajar Matematika Melalui Model Pembelajaran Cooperative Learning Tipe Student Team Achievement Division Siswa Kelas Iv Sdn 4 Sungai Langka Gedong Tataan Pesawaran," Skripsi (UNIVERSITAS LAMPUNG: FAKULTAS KEGURUAN DAN ILMU PENDIDIKAN, June 17, 2016), https://doi.org/10/15/SKRIPSI\%20TANPA\%20BAB\%20PEMBAHASAN.pdf.

6 I. Ketut Sudarsana, "Pengaruh Model Pembelajaran Kooperatif Terhadap Peningkatan Mutu Hasil Belajar Siswa," Jurnal Penjaminan Mutu 4, no. 1 (February 28, 2018): 20-31, https://doi.org/10.25078/jpm.v4i1.395.

${ }^{7}$ Karunia Eka Lestari, M. ridwan yudhanegara. (2015). Penelitian Pendidikan Matematika. (Anna, Ed.) (1st ed.). Bandung: PT Refika Aditama.

${ }^{8}$ Fajar Jefri Irawan and Ningrum Ningrum, "Pengaruh Penggunaan Model Cooperative Learning Tipe Group Investigation (GI) Terhadap Hasil Belajar Prakarya Dan Kewirausahaan 
model pembelajaran GI untuk melihat perbedaan peningkatan kemampuan repreentasi matematis siswa dan bagaimana kemampuan representasi matematis siswa ditinjau dari aktivitas belajar siswa.

\section{Metode}

Penelitian yang digunakan adalah penelitian mix-method untuk mengumpulkan data baik data kuantitatif maupun kualitatif dengan desain exploratory design. Populasi dalam penelitian ini adalah siswa kelas XI di salah satu SMA Negeri di Singkawang yang terdiri dari kelas XI IIS1, XI IIS2 dan XI MIA. Sampel dalam penelitian ini adalah kelas XI IIS1 sebagai kelas eksperimen dan XI IIS2 sebagai kelas control yang diambil secara purposive sampling. Instrumen yang digunakan berupa lembar tes kemampuan representasi matematis siswa, lembar observasi aktivitas dan wawancara.

Tes kemampuan representasi matematis siswa berupa soal essay yang sesuai dengan indikator kemampuan representasi matematis. Materi tes ditentukan berdasarkan materi ajar bidang studi matematika kelas XI SMA sesuai standar isi pada Kurikulum K-13. Teknik analisis data yang digunakan adalah dengan mencari nilai $N$-Gain, menguji normalitas data dan menggunakan statistika non parametrik mann-whitney U-test.

\section{Hasil dan Diskusi}

Sesuai dengan prosedur penelitian, hal pertama yang dilakukan adalah mengumpulkan data melalui soal essay yang telah disusun sesuai indikator kemampuan representasi matematis yang terdiri dari representasi visual, representasi persamaan atau ekspresi matematis, dan representasi kata atau teks tertulis. Kelas eksperimen adalah kelas yang diterapkan model pembelajaran GI sedangkan kelas kontrol diterapkan model pembelajaran langsung. Untuk kelas eksperimen, akan diobservasi bagaimana tingkat aktivitas belajar ketika diterapkan model pembelajaran $G I$.

Data hasil tes kemampuan representasi matematis siswa yang diperoleh dapat dilihat pada Tabel 1.

Tabel 1. Rekapitulasi Data Pretest-Posttest

\begin{tabular}{lllll}
\hline & \multicolumn{2}{l}{ Kelas Eksperimen } & Kelas Kontrol \\
\hline & Pretest & Posttest & Pretest & Posttest \\
\hline Rata-Rata & 45 & 82.381 & 44 & 60.4762 \\
\hline Standar deviasi & 8,89 & 11,84 & 9,48 & 10,40 \\
\hline
\end{tabular}

(Pkwu) Siswa Kelas X Semester Genap Smk Negeri 1 Metro Tp 2015-2016," PROMOSI: Jurnal Program Studi Pendidikan Ekonomi 4, no. 2 (November 30, 2016), https://doi.org/10.24127/ja.v4i2.641. 

Oktober-2020, Vol.8, No.2, hal.159-172

Berdasarkan Tabel 1 terlihat bahwa baik dikelas eksperimen maupun kelas kontrol memiliki nilai post-test yang lebih tinggi dibandingkan nilai pretest. Data tersebut selanjutnya akan diolah kembali untuk mengetahui perbedaan peningkaran kemampuan representasi matematis siswa dengan menggunakan uji $N$-gain. Hasilnya dapat dilihat pada Tabel 2.

Tabel 2. $N$-gain Tiap Indikator Kemampuan Representasi Matematis Siswa

\begin{tabular}{|c|c|c|c|c|c|c|c|c|}
\hline Indikator & \multicolumn{2}{|c|}{ Kls. Eksp } & \multicolumn{6}{|c|}{ Kls Kontrol } \\
\hline $\begin{array}{c}\text { Kemampuan } \\
\text { Representasi } \\
\text { Matematis }\end{array}$ & $\begin{array}{c}\text { Pre- } \\
\text { test }\end{array}$ & $\begin{array}{l}\text { Post } \\
\text {-test }\end{array}$ & $\begin{array}{c}N- \\
\text { gain }\end{array}$ & Kriteria & $\begin{array}{c}\text { Pre- } \\
\text { test }\end{array}$ & $\begin{array}{l}\text { Post } \\
\text {-test }\end{array}$ & $\begin{array}{c}N- \\
\text { gain }\end{array}$ & Kriteria \\
\hline $\begin{array}{l}\text { menyajikan } \\
\text { kembali data / } \\
\text { informasi dari } \\
\text { suatu } \\
\text { representasi } \\
\text { ke } \\
\text { representasi } \\
\text { diagram, } \\
\text { grafik/tabel }\end{array}$ & 3.95 & 7.7 & 0.74 & Tinggi & 4.5 & 6.1 & 0.36 & Sedang \\
\hline $\begin{array}{l}\text { membuat } \\
\text { persamaan } \\
\text { /model } \\
\text { matematika } \\
\text { dari } \\
\text { representasi } \\
\text { lain yang } \\
\text { diberikan }\end{array}$ & 2.1 & 4.45 & 0.60 & Sedang & 2.5 & 2.85 & 0.1 & Rendah \\
\hline $\begin{array}{l}\text { Menjawab soal } \\
\text { dengan } \\
\text { menggunakan } \\
\text { kata-kata/teks } \\
\text { tertulis }\end{array}$ & 3.3 & 5.15 & 0.69 & Sedang & 3.5 & 3.75 & 0.1 & Rendah \\
\hline
\end{tabular}

Untuk melihat perbedaan peningkatan antara kelas yang menggunakan model GI (kelas eksperimen) dan kelas yang menggunakan model pembelajaran langsung (kelas control), terlebih dahulu dilakukan uji normalitas $N$-gain dan uji homogenitas $N$-gain. Hasil analisis uji normalitas dapat dilihat pada Tabel 3.

Tabel 3 Hasil Perhitungan Normalitas Data N-gain

\begin{tabular}{ccc}
\hline & $\boldsymbol{N}$-gain Kelas Eksperimen & $\boldsymbol{N}$-gain Kelas Kontrol \\
\hline $\boldsymbol{x}^{\mathbf{2}}{ }_{\text {hitung }}$ & 1,876 & 22,39 \\
$\boldsymbol{x}^{\mathbf{2}}$ tabel & 9,488 & 9,488 \\
\hline
\end{tabular}


Berdasarkan Tabel 3, dapat dilihat bahwa data $N$-gain pada kelas eksperimen $x^{2}{ }_{\text {hitung }} \leq x^{2}$ tabel yaitu 1,876 $\leq 9,488$ maka data $N$-gain kelas eksperimen berdistribusi normal. Sedangkan pada kelas kontrol $x^{2}{ }_{\text {hitung }}>$ $x^{2}$ tabel yaitu $22,39 \leq 9,488$ maka data $N$-gain kelas kontrol tidak berdistribusi normal. Langkah selanjutnya adalah dengan perhitungan statistik non parametrik yaitu uji $U$ mann-whitney dikarenakan terdapat salah satu data tidak berdistribusi normal. Berdasarkan perhitungan yang dilakukan bahwa $\mathrm{Z}_{\text {hitung }}<\mathrm{Z}_{\text {tabel }}$ yaitu $(-4,52<-1,96)$ maka $\mathrm{H}_{0}$ ditolak dan $\mathrm{Ha}_{\mathrm{a}}$ diterima. Artinya terdapat perbedaan peningkatan kemampuan representasi matematis siswa yang diberikan model pembelajaran GI dengan siswa yang diberikan model pembelajaran langsung pada materi turunan. Hal ini sejalan dengan hasil penelitian Mumun Syaban yang menunjukkan model pembelajaran problem based learning melalui grup investigasi mampu meningkatkan minat dan prestasi belajar siswa ${ }^{9}$. Hasil penelitian Citra Utami dan kawan-kawan juga menunjukan bahwa ketuntasan belajar kelas yang diberi pembelajaran model generatif dengan strategi GI tercapai dan lebih baik daripada kelas kontrol. Hal ini menunjukkan bahwa pembelajaran yang diberikan berhasil meningkatkan kemampuan komunikasi matematis siswa pada materi trigonometri ${ }^{10}$.

Selanjutnya dilakukan analisis terhadap hasil tes kemampuan representasi matematis siswa dan aktivitas belajar siswa kelas eksperimen. ditinjau dari aktivitas belajar siswa dengan cara kategorisasi. Kategori aktivitas belajar siswa bervariasi, ada siswa yang tergolong aktivitas belajarnya tinggi, aktivitas belajarnya cukup dan aktivitas belajar rendah. Siswa dengan kategori aktivitas belajar aktif, memiliki kemampuan representasi matematis tinggi. Siswa dengan kategori aktivitas belajar cukup, cenderung memiliki kemampuan representasi matematis sedang. Kecenderungan yang sama ditunjukkan oleh siswa dengan kategori aktivitas belajar rendah. Rekapitulasi kategorisasi aktivitas dan kemampuan representasi matematis siswa dapat dilihat pada Tabel 4.

${ }^{9}$ Agung Cahyono, "Penerapan Problem Based Learning Melalui Grup Investigasi Untuk Meningkatkan Minat Dan Prestasi Belajar Sejarah Bagi Siswa Kelas XI IPA 3 SMA Negeri 1 Sampang Kabupaten Cilacap Pada Semester 2 Tahun Pelajaran 2014-2015" (PhD Thesis, UNS (Sebelas Maret University), 2015).

${ }^{10}$ Citra Utami, Dwijanto, and Djuniadi, "Pembelajaran Model Generatif Dengan Strategi Group Investigation Untuk Meningkatkan Kemampuan Komunikasi Matematis Siswa," Unnes Journal of Mathematics Education Research 4, no. 1 (2015), https://journal.unnes.ac.id/sju/index.php/ujmer/article/view/6904. 

Oktober-2020, Vol.8, No.2, hal.159-172

Tabel 4. Rekapitulasi Analisis Kategori Kemampuan Representasi Matematis Siswa Ditinjau Dari Aktivitas Belajar Siswa

\begin{tabular}{lcc}
\hline Kategori Aktivitas & Kategori Kemampuan & Banyak Siswa \\
\hline \multirow{3}{*}{ Aktif } & Tinggi & 6 \\
\cline { 2 - 3 } & Sedang & - \\
\cline { 2 - 3 } Cukup & Rendah & - \\
\cline { 2 - 3 } & Tinggi & 4 \\
\hline \multirow{3}{*}{ Pasif } & Sedang & 7 \\
\cline { 2 - 3 } & Rendah & - \\
\hline & Tinggi & - \\
\hline
\end{tabular}

Berdasarkan pengelompokan siswa yang ada pada Tabel 4, masingmasing kelompok kategori akan diambil 1 orang sebagai sampel untuk diwawancara, yaitu 1 siswa yang aktivitas belajarnya tinggi (aktif) dan berkemampuan representasi tinggi, 1 orang siswa yang aktivitas belajarnya sedang dan berkemampuan representasi tinggi, 1 orang siswa yang aktivitas belajarnya sedang dan berkemampuan representasi sedang, 1 orang siswa yang aktivitas belajarnya rendah (pasif) dan berkemampuan representasi sedang dan yang terakhir 1orang siswa yang aktivitas belajarnya rendah (pasif) dan berkemampuan representasi rendah, maka total siswa yang akan diwawancara ada 5 orang.
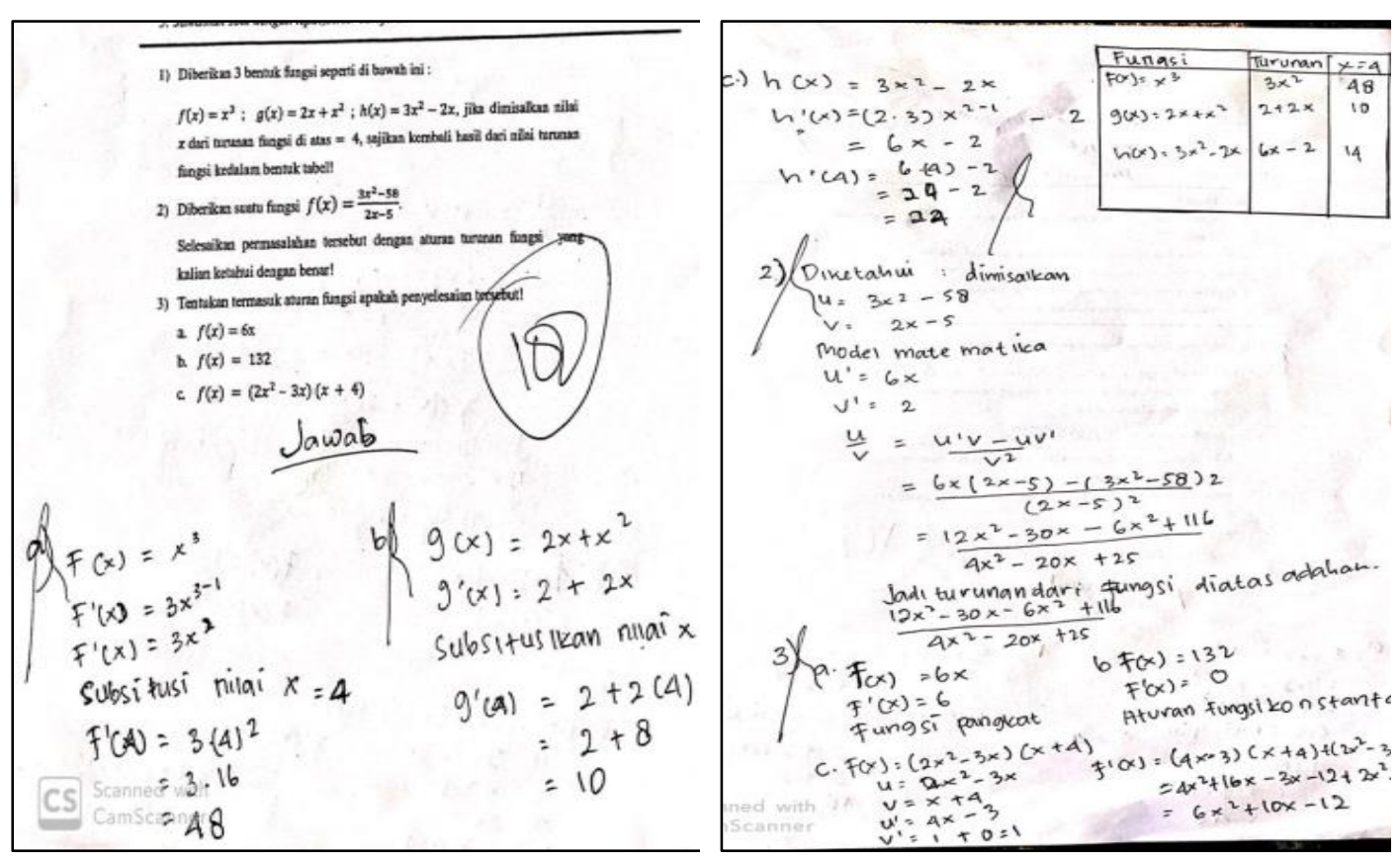

Gambar 1. Lembar Jawaban Siswa Berkemampuan Representasi Matematis Tinggi dengan Aktivitas Belajar Aktif 
Dari Gambar 1 terlihat bahwa siswa yang memiliki kemampuan representasi matematis tinggi dengan aktivitas belajar aktif dapat menyelesaikan ketiga soal dengan sangat baik. Pada soal nomor 1 siswa dapat menyajikan kembali penyelesaian dari soal turunan yang diberikan ke dalam bentuk tabel dengan baik dan benar. Pada soal nomor 2 siswa dapat menyelesaikan soal turunan dengan pemodelan matematika dengan baik runtun dan benar. Pada soal nomor 3 siswa juga dapat menyelesaikan soal turunan menggunakan teks tertulis secara lengkap dan benar. Berdasarkan wawancara yang dilakukan terdapat konsistensi antara hasil tes dan hasil wawancara. Siswa menjawab setiap pertanyaan berdasarkan soal yang telah dikerjakan dengan sangat baik.

Siswa yang memiliki kemampuan representasi tinggi dengan aktivitas belajar cukup dapat menyelesaikan soal dengan baik. Pada soal nomor 1 siswa dapat menyajikan dengan baik dan benar penyelesaian dari soal turunan yang diberikan kedalam bentuk tabel. Pada soal nomor 2 siswa dapat menyelesaikan dengan baik soal turunan dengan pemodelan matematika, hanya saja masih kurang lengkap dengan tidak membuat kesimpulannya. Pada soal nomor 3 siswa dapat menyelesaikan soal turunan menggunakan teks tertulis dengan baik tetapi tidak lengkap. Siswa langsung menuliskan sifat dari turunan tersebut tanpa mencari nilai turunannya terlebih dahulu. Pada saat diwawancara siswa menjawab sesuai dengan yang telah dia kerjakan pada lembar jawaban. Artinya terdapat konsistensi antara hasil tes dan hasil wawancara.
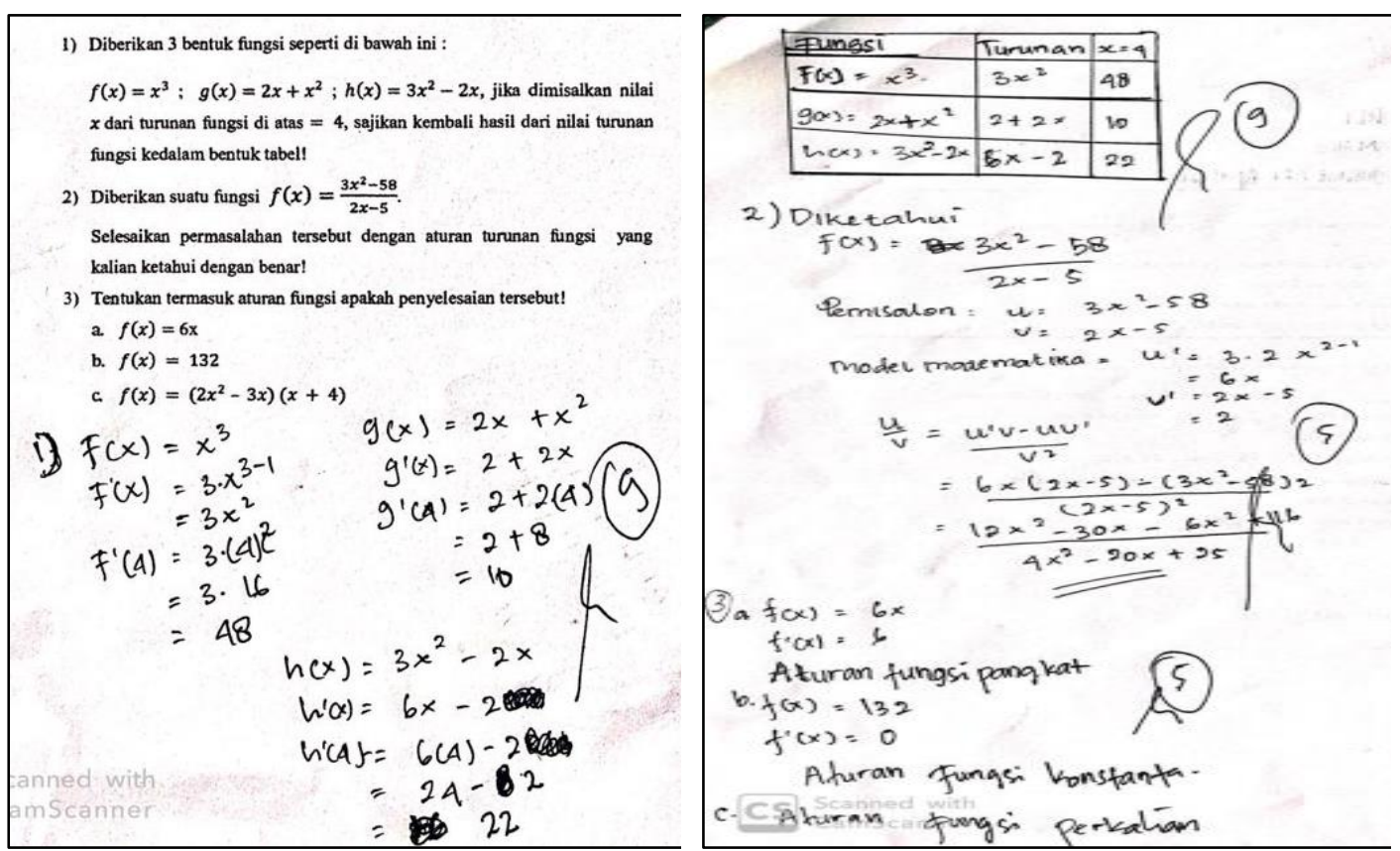

Gambar 2. Lembar Jawaban Siswa Berkemampuan Representasi Matematis Tinggi dengan Aktivitas Belajar Cukup Baik 
Dari Gambar 2 terlihat bahwa siswa yang memiliki kemampuan representasi tinggi dengan aktivitas belajar yang cukup baik dapat menyelesaikan soal dengan baik. Pada soal nomor 1 siswa dapat menyajikan kembali penyelesaian dari soal turunan yang diberikan kedalam bentuk tabel dengan baik dan benar. Pada soal nomor 2 siswa dapat menyelesaikan soal turunan dengan pemodelan matematika dengan baik hanya saja masih kurang lengkap dimana siswa tersebut tidak mebuat kesimpulan dari soal nomor 2. Pada soal nomor 3 siswa dapat menyelesaikan soal turunan menggunakan teks tertulis dengan baik tetapi tidak lengkap. Siswa langsung menuliskan sifat dari turunan tersebut tanpa mencari nilai turunannya terlebih dahulu. Pada saat diwawancara siswa menjawab sesuai dengan apa yang telah dikerjakan. Artinya terdapat konsistensi antara hasil tes dan hasil wawancara.
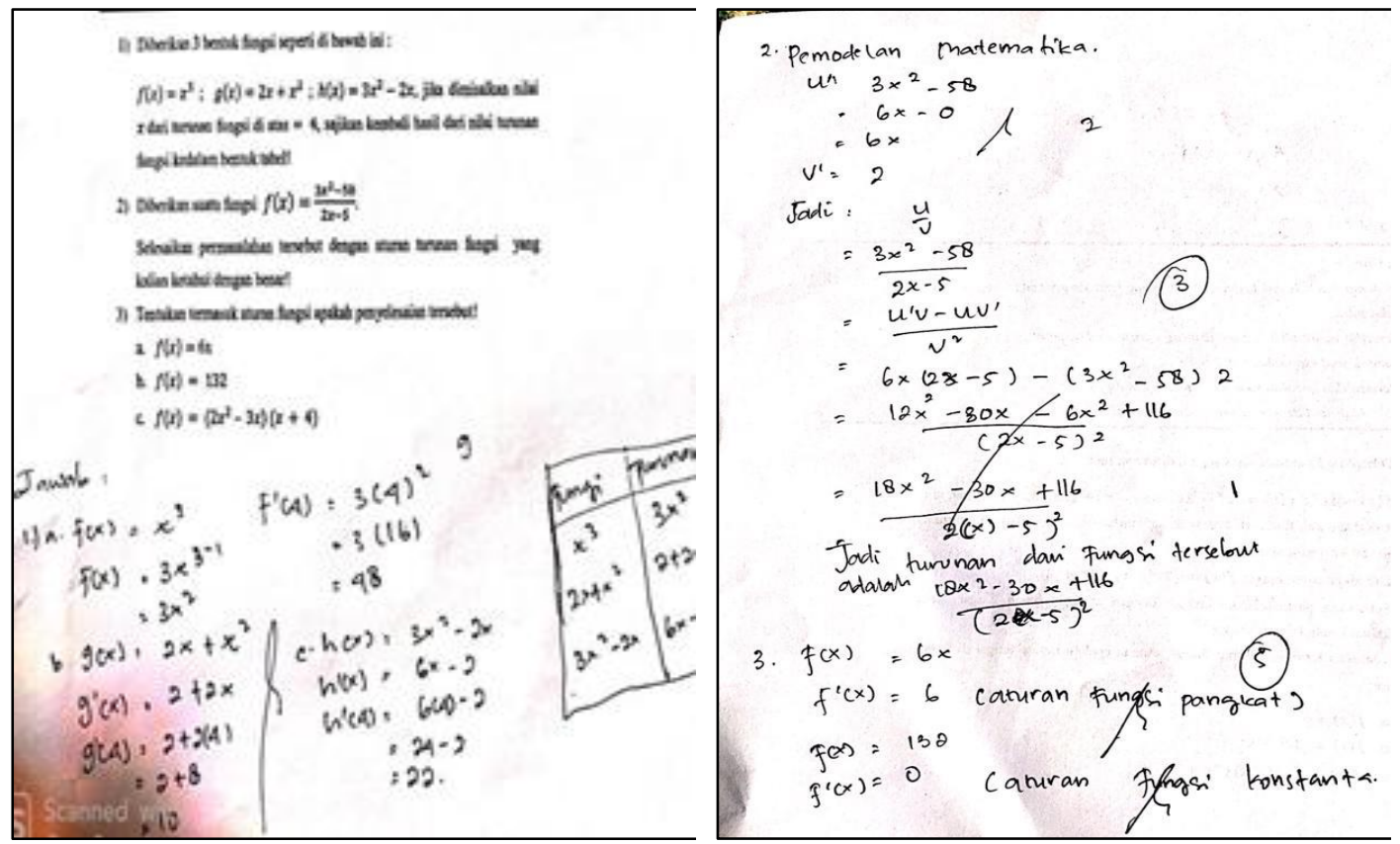

Gambar 3.Lembar Jawaban Siswa Berkemampuan Representasi Matematis Sedang dengan Aktivitas Belajar Cukup

Dari Gambar 3 terlihat bahwa untuk siswa yang memiliki kemampuan representasi sedang dengan aktivitas belajar yang cukup baik dapat menyelesaikan soal dengan cukup baik. Pada soal nomor 1 siswa dapat mencari hasil dari turunan dengan benar namun siswa kurang tepat dalam menuliskan pensubstitusian nilai x kedalam bentuk tabel. Pada soal nomor 2 siswa dapat menyelesaikan soal turunan dengan pemodelan matematika dengan baik namun kurang lengkap, didalam penyelesaian soal tersebut siswa tidak melakukan pemisalan terlebih dahulu. Pada soal nomor 3 siswa dapat menyelesaikan soal turunan menggunakan teks tertulis dengan baik tetapi tidak lengkap, dimana siswa langsung menuliskan sifat dari turunan 
tersebut tanpa mencari nilai turunannya terlebih dahulu. Berdasarkan wawancara yang dilakukan terdapat konsistensi antara hasil tes dan hasil wawancara sehingga untuk siswa dengan aktivitas belajar yang cukup kemampuan representasinya tergolong sedang.
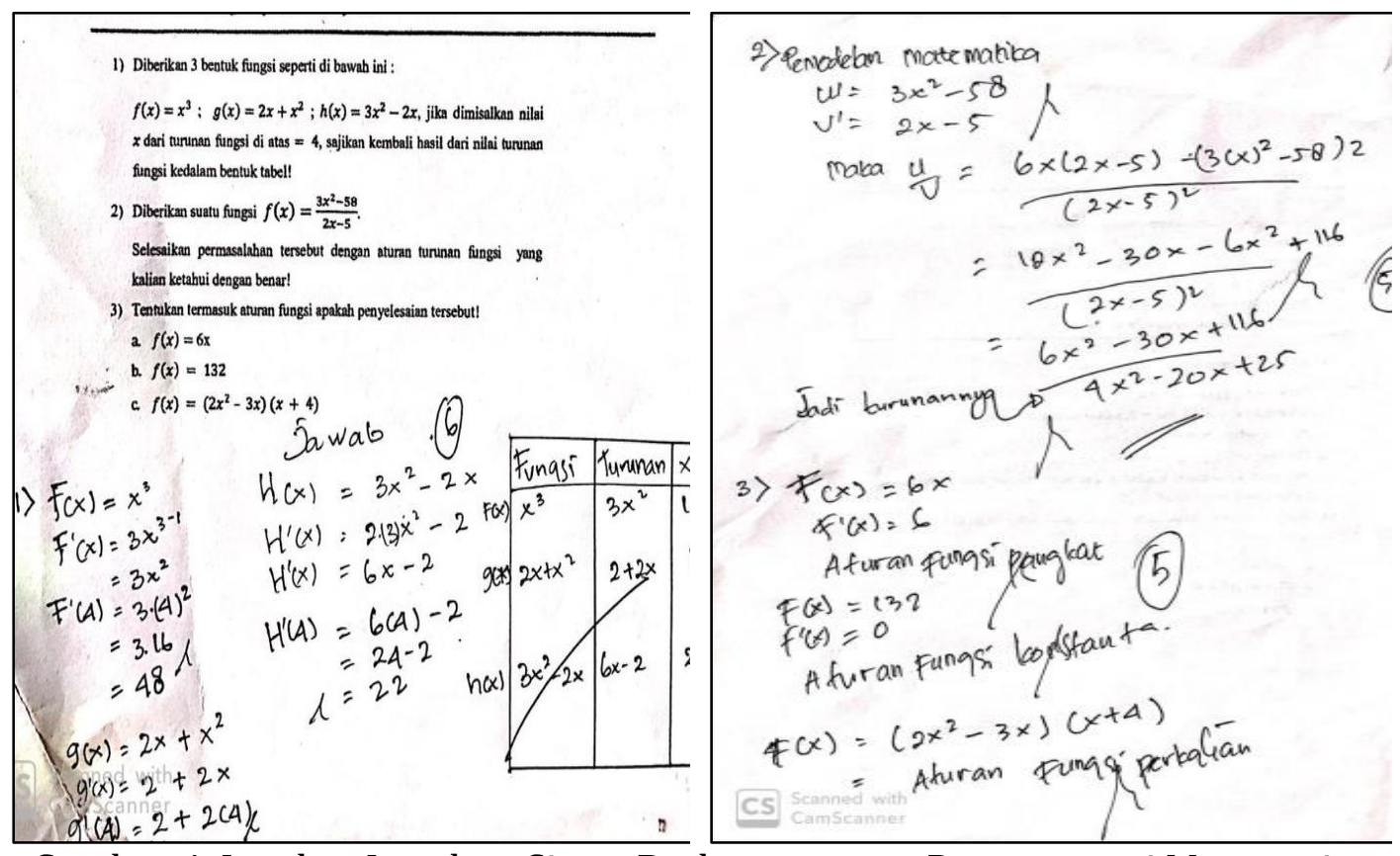

Gambar 4. Lembar Jawaban Siswa Berkemampuan Representasi Matematis Sedang dengan Aktivitas Belajar Pasif

Dari Gambar 4 terlihat bahwa untuk siswa yang memiliki kemampuan representasi sedang dengan aktivitas belajar rendah menyelesaikan soal dengan cukup baik. Pada soal nomor 1 siswa dapat mencari hasil dari turunan dengan benar dan lengkap serta tepat dalam menyajikan kembali hasil dari nilai turunan tersebut kedalam bentuk tabel. Pada soal nomor 2 siswa mengerjakan soal kurang lengkap dan kurang tepat dimana siswa tidak melakukan pemisalan dan hasil penyelesaian salah, namun siswa menyelesaikan soal menggunakan pemodelan matematika dengan benar. Pada soal nomor 3 siswa dapat menyelesaikan soal turunan menggunakan teks tertulis dengan baik tetapi tidak lengkap, dimana siswa langsung menuliskan sifat dari turunan tersebut tanpa mencari nilai turunannya. Berdasarkan wawancara yang dilakukan terdapat konsistensi antara hasil tes dan hasil wawancara namun untuk siswa sebenarnya memiliki kemampuan representasi yang cukup baik hanya saja untuk aktivitas siswa ini tergolong rendah karna siswa tidak aktif dan kurang berinteraksi dengan teman sekitarnya. 

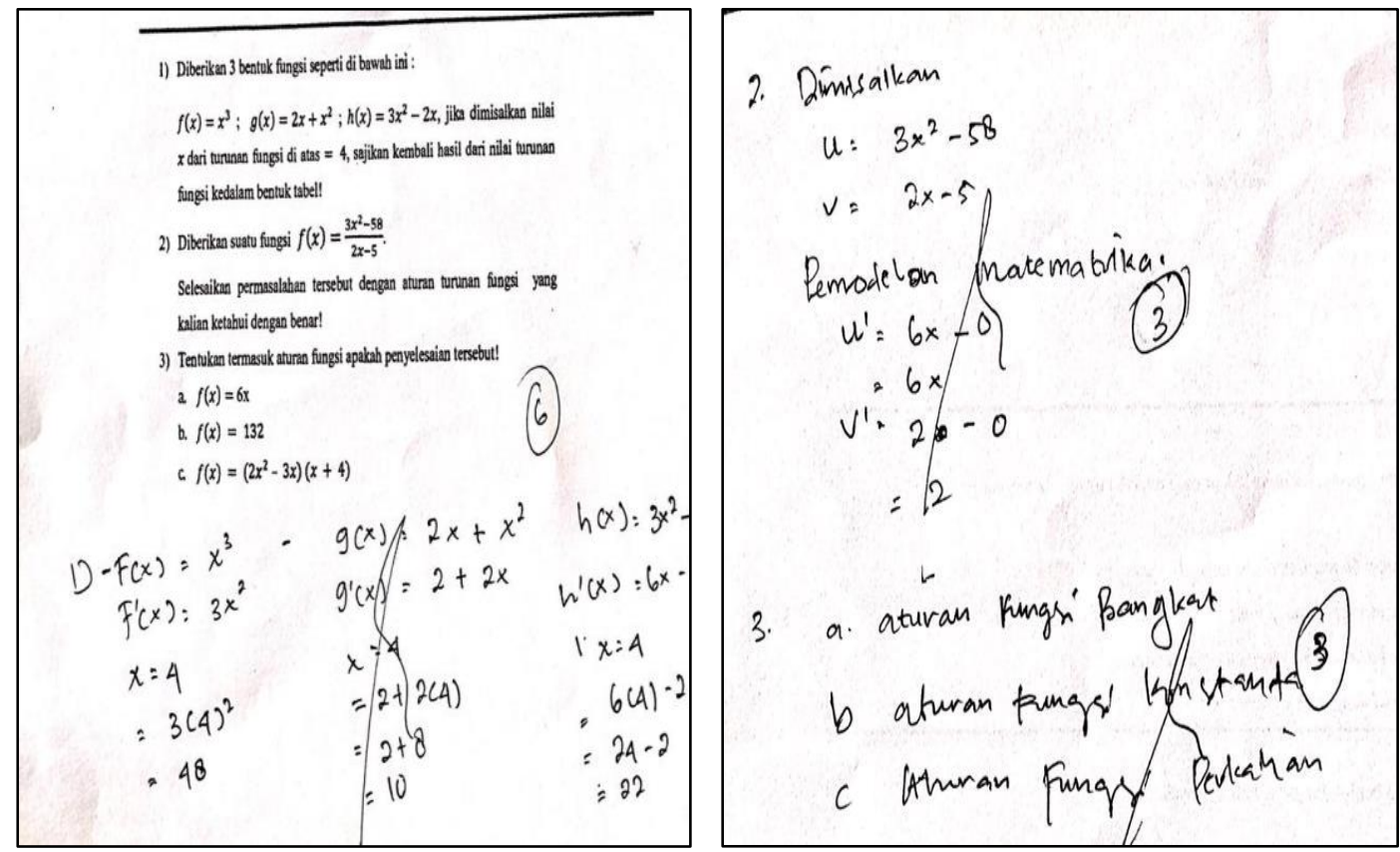

Gambar 5. Lembar Jawaban Siswa Berkemampuan Representasi Matematis Sedang dengan Aktivitas Belajar Pasif

Dari Gambar 5 terdilihat untuk soal nomor 1 siswa dapat mencari hasil dari turunan dengan benar namun tidak dapat menyajikan kembali hasil dari turunan yang telah diselesaikannya kedalam bentuk tabel. Pada soal nomor 2 siswa dapat membuat pemodelan matematika dengan baik hanya saja siswa tidak menyelesaikan soal tersebut dengan lengkap. Pada soal nomor 3 siswa dapat menyelesaikan soal turunan menggunakan teks tertulis dengan baik tetapi tidak lengkap, dimana siswa langsung menuliskan sifat dari turunan tersebut tanpa mencari nilai turunannya. Berdasarkan wawancara yang dilakukan terdapat konsistensi antara hasil tes dan hasil wawancara siswa tidak bisa mendeskripsikan jawaban dari tes yang sehingga data yang didapatkan valid.

Aktivitas belajar siswa yang baik ditunjukkan saat proses pembelajaran berlangsung dimana siswa terlihat sangat antusias dalam mengikuti pembelajaran yang menggunakan model GI. Karena pada tiap tahapan model pembelajaran GI dapat merangsang aktivitas belajar siswa. Pada tahapan yang pertama yaitu grouping siswa memilih sendiri rekan kelompoknya sehingga siswa dapat membentuk kelompok tanpa bantuan guru seperti bagaimana biasanya. Setelah siswa membentuk kelompoknya kemudian pada tahap kedua yaitu planning, siswa merencanakan sendiri bagaimana dan apa yang harus dikerjakan untuk menyelesaikan permasalahan yang diberikan. Pada tahap ketiga yaitu investigation, siswa mengidentifikasi dan menganalisis permasalahan yang diberikan. Kemudian pada tahap keempat yaitu organizing, siswa menyiapkan hasil investigsi sebelumnya. Pada tahap kelima yaitu presenting, perwakilan dari tiap kelompok siswa tersebut 
mempresentasikan hasil investigasinya. Terakhir tahap keenam evaluation, siswa dengan bimbingan guru melakukan evaluasi atas hasil investigasi yang telah dipresentasikan. Berdasarkan tahapan model pembelajaran GI tersebut siswa dituntut untuk aktif sehingga siswa lebih menonjol dari pada guru pada saat proses belajar mengajar berlangsung. Tingginya aktivitas belajar siswa setelah diimplementasikan GI di dalam penelitian ini, sejalan dengan hasil penelitian Nurhidayah yang menunjukkan penerapan model pembelajaran kooperatif tipe group investigation dapat meningkatkan aktivitas siswa pada materi bangun ruang dimensi tiga ${ }^{11}$. Begitupun penelitian Hija yang menunjukan aktivitas siswa tergolong sangat aktif dengan model pembelajaran GI pada materi peluang di kelas X MIPA SMA Negeri 1 Singkawang12. Dengan demikian, secara keseluruhannya aktivitas belajar siswa pada kelas dengan model Pembelajaran GI lebih baik dibandingkan dengan aktivitas siswa yang menerapkan model pembelajaran langsung.

\section{Kesimpulan}

Artikel ini telah menunjukkan adanya perbedaan tingkat kemampuan representasi matematis siswa yang diberikan model pembelajaran Group Investigation (GI) dengan siswa yang diberikan model pembelajaran langsung pada materi turunan. Siswa terlihat sangat antusias dalam mengikuti pembelajaran menggunakan model GI. Hal ini disebabkan pada tiap tahapan model pembelajaran GI dapat merangsang aktivitas belajar siswa yang menyebabkan siswa lebih aktif dari pada guru. Siswa dengan kategori aktivitas belajar aktif, memiliki kemampuan representasi matematis tinggi. Siswa dengan kategori aktivitas belajar cukup, cenderung memiliki kemampuan representasi matematis sedang. Kecenderungan yang sama ditunjukkan oleh siswa dengan kategori aktivitas belajar rendah.

11 Dwi Avita Nurhidayah, "Peningkatan Aktivitas Belajar Siswa Melalui Pembelajaran Kooperatif Tipe Group Investigasi Pada Materi Geometri," Jurnal Dimensi Pendidikan dan Pembelajaran 2, no. 2 (June 24, 2016): 43-50, https://doi.org/10.24269/dpp.v2i2.151.

12 Alvia Hija, Resy Nirawati, and Nindy Citroresmi Prihatiningtyas, "Pengaruh Model Pembelajaran Group Investigation (GI) Terhadap Kemampuan Pemecahan Masalah Matematis Siswa Pada Materi Peluang Kelas X MIPA," JPMI (Jurnal Pendidikan Matematika Indonesia) 1, no. 1 (March 1, 2016): 25-33, https://doi.org/10.26737/jpmi.v1i1.79. 


\section{Daftar Pustaka}

Cahyono, Agung. "Penerapan Problem Based Learning Melalui Grup Investigasi Untuk Meningkatkan Minat Dan Prestasi Belajar Sejarah Bagi Siswa Kelas XI IPA 3 SMA Negeri 1 Sampang Kabupaten Cilacap Pada Semester 2 Tahun Pelajaran 2014-2015." PhD Thesis, UNS (Sebelas Maret University), 2015.

Dewi, Izwita, Sahat Saragih, and Dewi Khairani. "Analisis Peningkatan Kemampuan Representasi Matematis Siswa SMA Ditinjau Dari Perbedaan Gender." Jurnal Didaktik Matematika 4, no. 2 (October 4, 2017): 115-24. https://doi.org/10.24815/jdm.v4i2.8863.

Handayani, Hani. "Pengaruh Pembelajaran Kontekstual Terhadap Kemampuan Pemahaman Dan Representasi Matematis Siswa Sekolah Dasar." Didaktik : Jurnal Ilmiah PGSD STKIP Subang 1, no. 1 (December 31, 2015): 142-49. https://doi.org/10.36989/didaktik.v1i1.20.

Hija, Alvia, Resy Nirawati, and Nindy Citroresmi Prihatiningtyas. "Pengaruh Model Pembelajaran Group Investigation (GI) Terhadap Kemampuan Pemecahan Masalah Matematis Siswa Pada Materi Peluang Kelas X MIPA." JPMI (Jurnal Pendidikan Matematika Indonesia) 1, no. 1 (March 1, 2016): 25-33. https://doi.org/10.26737/jpmi.v1i1.79.

Irawan, Fajar Jefri, and Ningrum Ningrum. "Pengaruh Penggunaan Model Cooperative Learning Tipe Group Investigation (GI) Terhadap Hasil Belajar Prakarya Dan Kewirausahaan (Pkwu) Siswa Kelas X Semester Genap Smk Negeri 1 Metro Tp 2015-2016." PROMOSI: Jurnal Program Studi Pendidikan Ekonomi 4, no. 2 (November 30, 2016). https://doi.org/10.24127/ja.v4i2.641.

Nurhayati, Sugi. "Meningkatkan Aktivitas Dan Hasil Belajar Matematika Melalui Model Pembelajaran Cooperative Learning Tipe Student Team Achievement Division Siswa Kelas Iv Sdn 4 Sungai Langka Gedong Tataan Pesawaran." Skripsi. UNIVERSITAS LAMPUNG: FAKULTAS KEGURUAN DAN ILMU PENDIDIKAN, June 17, 2016. https://doi.org/10/15/SKRIPSI\%20TANPA\%20BAB\%20PEMBAHASA N.pdf.

Nurhidayah, Dwi Avita. "Peningkatan Aktivitas Belajar Siswa Melalui Pembelajaran Kooperatif Tipe Group Investigasi Pada Materi Geometri." Jurnal Dimensi Pendidikan dan Pembelajaran 2, no. 2 (June 24, 2016): 43-50. https://doi.org/10.24269/dpp.v2i2.151.

Sabirin, Muhamad. "Representasi dalam Pembelajaran Matematika." Jurnal Pendidikan Matematika 1, no. 2 (August 19, 2014): 33-44. https://doi.org/10.18592/jpm.v1i2.49.

Sudarsana, I. Ketut. "Pengaruh Model Pembelajaran Kooperatif Terhadap Peningkatan Mutu Hasil Belajar Siswa." Jurnal Penjaminan Mutu 4, no. 1 (February 28, 2018): 20-31. https://doi.org/10.25078/jpm.v4i1.395.

Utami, Citra, Dwijanto, and Djuniadi. "Pembelajaran Model Generatif Dengan Strategi Group Investigation Untuk Meningkatkan Kemampuan Komunikasi Matematis Siswa." Unnes Journal of Mathematics Education Research 4, no. 1 (2015). https://journal.unnes.ac.id/sju/index.php/ujmer/article/view/6904. 
172 Putri Sucita Sari, dkk /Al-Khwarizmi: Jurnal Pendidikan Matematika dan Ilmu Pengetahuan Alam, Oktober-2020, Vol.8, No.2, hal.159-172

Yunita, Seswira, Lies Andriani, and Ade Irma. "Pengaruh Penerapan Model Pembelajaran Kooperatif Tipe Group Investigation Terhadap Kemampuan Pemecahan Masalah Matematis Ditinjau Dari Motivasi Belajar Siswa Sekolah Menengah Pertama Di Kampar." JURING (Journal for Research in Mathematics Learning) 1, no. 1 (May 27, 2018): 11-18. https://doi.org/10.24014/juring.v1i1.4700. 